\title{
Research on the influence of government subsidies on the growth of energy-based enterprises—-The mediating effect of enterprise R\&D investment
}

\author{
Yue Qin ${ }^{1}$, Wu Zhixuan, ${ }^{2, *}$ \\ ${ }^{1}$ School of management, Dalian Polytechnic University, Dalian, Liaoning, China \\ ${ }^{2}$ School of management, Dalian Polytechnic University, Dalian, Liaoning, China
}

\begin{abstract}
Energy is the material basis for the survival and development of human society. It is of great significance for energy enterprises to obtain government subsidies, improve technological innovation ability, improve energy efficiency and realize sustainable development. Based on the data of listed energy companies in China, this paper examines the relationship between government subsidies, R \& D investment and the growth of energy companies. The results show that: there is a significant positive correlation between government subsidies and the growth of energy enterprises; there is a significant positive correlation between government subsidies and R \& D investment; R \& D investment has a significant partial mediating effect between government subsidies and the performance of resource-based enterprises.
\end{abstract}

\section{Preface}

Energy is the material basis for the survival and development of human society, and has a very important strategic position in the national economy. Energy enterprises are an important part of Chinese enterprises. The relationship between energy enterprises and China's economy, on the one hand, is to adapt to the needs of national economic development, extensive development and utilization of energy, to provide power for social development; on the other hand, in the use of "open source", at the same time, to comprehensively "cut", through technological innovation and other means to improve energy efficiency, with the least energy to promote the growth of enterprises, to make contributions to the rapid development of the national economy Contribution. In order to improve the business situation of enterprises, encourage R\&D activities, and improve the stable development ability of enterprises, the state increases the support for energy enterprises, especially the government provides key support for new energy enterprises. At present, enterprises also have a lot of $\mathrm{R} \& \mathrm{D}$ investment and innovation achievements. However, energy enterprises still face many difficulties in operation, and there are many problems behind the high subsidies. Therefore, it is necessary to study the relationship between government support, $R \& D$ investment and the growth of energy enterprises. Therefore, starting from the mediating effect of $\mathrm{R} \& \mathrm{D}$, this paper studies the relationship between government subsidies and the growth of listed companies. It also helps energy enterprises to make rational use of government subsidies, increase R\&D investment, and promote the healthy growth of enterprises.

\section{Literature review and research hypothesis}

\subsection{Government subsidy and enterprise growth}

In order to promote the development of enterprises, the government provides preferential policies and financial support for enterprises. However, scholars at home and abroad have done a lot of research on whether government subsidies are conducive to the development of enterprises. So far, the answer to this question is still controversial.

Some scholars believe that government subsidies are beneficial to the development of enterprises. Cerqua et al (2014) research on Italian financial support policy shows that financial support can significantly improve staff size, investment level and company growth. Kong Dongmin et al. (2014) showed that government subsidies can improve the business performance and social responsibility of private enterprises. Compared with the state-owned enterprises, the government subsidies have a more obvious role in promoting the business performance and social responsibility of private enterprises. Li Chuanxian and Liu Xiaoyu (2016) take the listed companies of private enterprises in China as samples. Through empirical research, we can draw the conclusion that the implementation of subsidies can significantly promote the growth of private enterprises.

Some scholars hold the opposite view that government subsidies will not promote the development

\footnotetext{
*Corresponding author: 865496126@qq.com
} 
of enterprises. Wei Zhihua et al. (2015) used the data of listed energy companies to study the relationship between government support and enterprise growth, and the results showed that government support did not promote the growth of enterprises. Cao Yanqiao et al. (2019) took A-share listed companies in coastal cities of Shandong Province as an example to conduct empirical research, and concluded that government subsidies did not promote the listed companies, but had a negative impact.

Considering the economic characteristics of energy enterprises, this paper believes that the government subsidies will enhance their economic benefits and bring positive effects for the development of enterprises. Therefore, this paper puts forward hypothesis 1 .

H1: government subsidies are positively correlated with the growth of resource-based enterprises.

\subsection{Government subsidy and R\&D investment}

Zhu Pingfang and Xu Weimin (2003) investigated the impact of fiscal expenditure and preferential tax policies on R\&D expenditure of Shanghai enterprises. Both policies can promote enterprises to increase their R\&D and expenditure, and found that the two policies are complementary. Zhao Kangsheng (2017) found that government R\&D subsidies can continuously promote enterprise R\&D investment through empirical research. And the stronger the absorptive capacity of enterprises, the better the promotion effect of Government R\&D subsidies on R\&D investment. Wu jian5 et al. (2018) analyzed the relationship between government subsidies and $R \& D$ investment of strategic emerging enterprises from the perspective of signal transmission, and concluded that government subsidies have a positive impact on R\&D investment. Zhu Zhihong and other (2019) new energy listed companies have conducted research, and the results show that government subsidies have played a significant role in promoting $R \& D$ investment and improving the financial ability of enterprises, but all of them have a certain degree of delay.Through the fixed effect test, Su Yi et al. (2021) found that government subsidies can promote the R\&D investment of new energy enterprises, rather than "crowding out" effect. This effect is significant only when it lags one cycle, but not when it lags two cycles. Government subsidy is the cost of $R \& D$ projects, which encourages enterprises to invest in $R \& D$ projects. In addition, if enterprises get special R\&D subsidies from the government or enjoy preferential tax policies from the government, they will increase $\mathrm{R} \& \mathrm{D}$ efforts and actively explore technology development trends, so as to enhance enterprise performance. Therefore, hypothesis 2 is proposed.

$\mathrm{H} 2$ : the R\&D input of energy enterprises is positively correlated with government subsidies.

\subsection{Government subsidies, R\&D investment and enterprise growth}

The existing research focuses on the relationship between government subsidies, R\&D investment and enterprise growth, but there are few literatures on the three within the same framework, which is also the innovation of this paper.

The existing research focuses on the relationship between government subsidies, R\&D investment and enterprise growth, but there are few literatures on the three within the same framework, which is also the innovation of this paper.

Zang Zhipeng (2015) takes cultural listed enterprises as the research object, and concludes that R\&D investment can have a significant positive mediating effect on the relationship between government subsidies and enterprise development in both the current period and the lag period. Zhuang wanting et al. (2018) showed that the R\&D investment of enterprises played a partial intermediary role in the relationship between government subsidies and enterprise development. Cao Yang et al. (2018) analyzed the results from the perspective of the scale of government subsidies, and found that with the increase of the scale of government subsidies, the R\&D investment of enterprises did not increase, but decreased, which had a negative impact on the development of enterprises to a certain extent. Zhang Shuanglan et al. (2019) took the data of listed manufacturing companies in China as samples, and found that government subsidies did not form a coordination effect with R\&D investment, but weakened the effect of R\&D investment on enterprise performance. Xu Fang et al. (2020), taking enterprise $\mathrm{R} \& \mathrm{D}$ investment as intermediary variable, empirically studied the impact of government subsidies on enterprise growth. R\&D investment plays a partial positive intermediary effect between government subsidies and enterprise growth.

When the government provides subsidies to enterprises, enterprises should bear the corresponding social responsibility. Therefore, the enterprise management pays more attention to the R\&D activities, and effectively uses the subsidy funds for R\&D investment, so as to improve the R\&D innovation ability and the growth ability of the enterprise. Therefore, this paper puts forward hypothesis 3 .

H3: R\&D investment of energy enterprises has a significant mediating effect between government subsidies and enterprise growth.

\section{Research design}

\subsection{Sample selection and data sources}

This paper mainly studies the mainstream energy industry, namely traditional energy industry and new energy industry listed companies. Based on the data of Listed Companies in CSMAR database from 2015 to 2019, this paper selects research samples according to industry categories, and eliminates all st and * ST listed companies and sample enterprises with missing data in three years, so as to ensure the validity of the data. Finally, 501 enterprises are included for research. The data in this paper are all from CSMAR database, and the 
analysis software is stata15.0.

\subsection{Variable design}

(1) Explained variable

Explained variables, choose the growth of enterprises. Based on the research of Zhang shuanxing (2017), Shan Chunxia and other scholars (2017), this paper selects the growth rate of operating revenue as the index for analysis:

Growth rate of operating revenue $=$ (amount of operating revenue in current period of this year - amount of operating revenue in the same period of last year) / (amount of operating revenue in the same period of last year)

Business income is the source of enterprise profits. The rise or fall of business income also indicates that enterprise profits may rise or fall. The growth rate of business income is also an important index to evaluate the growth status and development ability of enterprises.

(2) Explanatory variables and control variables

The explanatory variables are government subsidies and $\mathrm{R} \& \mathrm{D}$. In order to eliminate heteroscedasticity and reduce the fluctuation of data, we choose to take logarithm. The control variables selected in this paper are asset liability ratio, current asset turnover, enterprise scale and equity concentration. The variable design is shown in Table 1.

Table 1. Variable definition table

\begin{tabular}{|c|c|c|c|}
\hline Name & Symbol & Definition & Remarks \\
\hline Enterprise growth & GRO & $\begin{array}{c}\text { Growth rate of operating revenue = (amount of operating revenue in current } \\
\text { period of this year - amount of operating revenue in the same period of last } \\
\text { year) / (amount of operating revenue in the same period of last year) }\end{array}$ & $\begin{array}{c}\text { Explained } \\
\text { variable }\end{array}$ \\
\hline $\begin{array}{c}\text { Government } \\
\text { subsidy }\end{array}$ & SUB & Natural logarithm of government subsidies & $\begin{array}{c}\text { Explanatory } \\
\text { variable }\end{array}$ \\
\hline $\begin{array}{c}\text { R\&D investment } \\
\text { Asset liability } \\
\text { ratio }\end{array}$ & R\&D & Natural logarithm of R\&D investment & $\begin{array}{c}\text { Explanatory } \\
\text { variable }\end{array}$ \\
\hline $\begin{array}{c}\text { Turnover of } \\
\text { current assets }\end{array}$ & LIQ & Total liabilities / total assets & $\begin{array}{c}\text { Control } \\
\text { variable }\end{array}$ \\
\hline $\begin{array}{c}\text { Enterprise scale } \\
\text { Onf }\end{array}$ & SIZE & Net main business income / average total current assets & $\begin{array}{c}\text { Control } \\
\text { variable }\end{array}$ \\
\hline $\begin{array}{c}\text { Ownership } \\
\text { concentration }\end{array}$ & OWN & The sum of the shareholding ratio of the top 10 major shareholders of the \\
company & $\begin{array}{c}\text { Control } \\
\text { variable }\end{array}$ \\
\hline
\end{tabular}

\subsection{Model setting}

According to the hypothesis proposed in this paper, the following model is established:

$$
\begin{aligned}
& G R O=\alpha_{0}+\alpha_{1} S U B+\alpha_{2} L E V+\alpha_{3} L I Q+\alpha_{4} S I Z E \\
& +\alpha_{5} O W N+\alpha_{6} R O A
\end{aligned}
$$

$R \& D=\alpha_{0}+\alpha_{1} \mathrm{SUB}++\alpha_{2} \mathrm{LEV}+\alpha_{3} L I Q+\alpha_{4} S I Z E$ $+\alpha_{5} O W N+\alpha_{6} R O A$

$G R O=\alpha_{0}+\alpha_{1} \mathrm{SUB}+\alpha_{2} R \& D+\alpha_{3} \mathrm{LEV}+\alpha_{4} L I Q$ $+\alpha_{5} S I Z E+\alpha_{6} O W N+\alpha_{7} R O A$

\section{Empirical Analysis}

\subsection{Descriptive statistics}

According to the descriptive statistics in Table 2, the average growth of energy enterprises is 0.126 , The standard deviation is 0.327 , It shows that the overall growth of energy enterprises is good. The average value of government subsidies is 15.734 , but the highest value is 20.73 and the lowest value is 9.12 , which indicates that there is a large gap between government subsidies of different energy enterprises. After logarithmic processing, the average value of $R \& D$ is 17.67 , which indicates that the average R\&D investment of Energy listed companies is still large, and Energy listed companies generally pay more attention to $\mathrm{R} \& \mathrm{D}$ investment. But the standard deviation is 1.836 , which indicates that $R \& D$ investment is not very stable. In the control variables, the standard deviation of ownership concentration is the largest, which indicates that the ownership concentration is the most dispersed, and the ownership distribution of different enterprises is quite different. 
Table 2. Descriptive statistical results

\begin{tabular}{|c|c|c|c|c|c|}
\hline Variable & Obs & Mean & Std. Dev. & Min & Max \\
\hline LIQ & 1124 & 1.607 & 1.152 & .282 & 6.074 \\
\hline OWN & 1124 & 61.293 & 15.243 & 26.316 & 93.639 \\
\hline LEV & 1124 & .489 & .191 & .071 & .911 \\
\hline SIZE & 1124 & 23.009 & 1.447 & 20.368 & 26.66 \\
\hline GRO & 1124 & .126 & .327 & -.428 & 1.698 \\
\hline SUB & 1124 & 15.734 & 2.361 & 9.12 & 20.73 \\
\hline RD & 1124 & 17.67 & 1.836 & 12.505 & 21.519 \\
\hline ROA & 1124 & .027 & .054 & -.186 & .183 \\
\hline
\end{tabular}

\subsection{Regression analysis}

Table 3 shows the regression results of government subsidies on the growth of energy enterprises. Before the regression analysis, the data are retracted by $1 \%$, which eliminates the influence of extreme values on the regression results.

The first is the regression result of model one, that is, the regression result of government subsidy to enterprise growth. Government subsidies and enterprise growth are significant at $1 \%$ level. The correlation coefficient between government subsidy and enterprise growth is 0.020 , which shows that government subsidy to energy enterprises is beneficial to their growth and development, which is consistent with hypothesis 1 . For the control variables, the return on assets and the ratio of assets to liabilities are significant at the level of $1 \%$, and the current asset-liability ratio and equity concentration are significant at the level of $10 \%$, while the scale of the enterprise is not significant. The return on assets and the concentration of equity are positively correlated with the growth of enterprises, and the return on current assets is negatively correlated with the growth of enterprises.

According to the result of model two, the independent variable government subsidy and the control variable enterprise scale are all at the level of $10 \%$ significantly. The regression coefficient is 0.040 , which indicates that the government subsidy is positively correlated with the enterprise R\&D investment. If the government subsidy increases by 1 unit, the enterprise R\&D investment will increase by 0.040 units, which is consistent with hypothesis 2. Among the control variables, the enterprise size and the return rate of current assets are all significant at the level of $1 \%$, and all have a positive impact on the R\&D investment of the enterprise. Asset-liability ratio and equity concentration are significant at the level of $5 \%$, and have a negative impact on R\&D investment of energy enterprises. The return on assets is not significant.

From the regression results of model 3, when government subsidies and R\&D investment are used as independent variables to affect the growth of enterprises, they are significant at the level of $1 \%$, the control variables asset liability ratio and return on assets are significant at the level of $1 \%$, the ownership concentration and return on current assets are significant at the level of $10 \%$, but the enterprise size is not significant. Referring to the stepwise regression test method of mediating effect of Wen Zhonglin (2014), considering the regression results, the mediating effect is tenable, that is, hypothesis 3 is tenable. And it is partial mediating effect,that is to say, when government subsidies affect the growth of enterprises, part of them are direct effects, and part of them are through $R \& D$ investment.

Table3. Regression results

\begin{tabular}{|c|c|c|c|}
\hline & (1) & (2) & (3) \\
\hline \multirow[t]{2}{*}{$\mathrm{RD}$} & & & $0.000 * * *$ \\
\hline & & & $(0.34)$ \\
\hline \multirow[t]{2}{*}{ SUB } & $0.020 * * *$ & $0.040^{*}$ & $0.000 * * *$ \\
\hline & $(4.76)$ & (1.75) & (4.13) \\
\hline \multirow[t]{2}{*}{ SIZE } & -0.007 & $0.577 * * *$ & -0.009 \\
\hline & $(-0.85)$ & (12.13) & $(-0.91)$ \\
\hline \multirow[t]{2}{*}{ LEV } & $0.215 * * *$ & $-0.811 * *$ & $0.217 * * *$ \\
\hline & (3.39) & $(-2.37)$ & $(3.40)$ \\
\hline \multirow[t]{2}{*}{ OWN } & $0.001 *$ & $-0.009 * *$ & $0.001 *$ \\
\hline & (1.79) & $(-2.53)$ & (1.81) \\
\hline \multirow[t]{2}{*}{ LIQ } & $-0.016^{*}$ & $0.131 * * *$ & $-0.016^{*}$ \\
\hline & $(-1.85)$ & (2.89) & $(-1.87)$ \\
\hline \multirow[t]{2}{*}{ ROA } & $2.128 * * *$ & 1.170 & $2.126^{* * *}$ \\
\hline & (11.20) & (1.14) & (11.17) \\
\hline \multirow[t]{2}{*}{$\begin{array}{l}\text { Consta } \\
\mathrm{nt}\end{array}$} & $0.407 * *$ & $4.458 * * *$ & $4.299 * * *$ \\
\hline & $(2.45)$ & (4.98) & (4.98) \\
\hline $\begin{array}{l}\text { Observ } \\
\text { ations }\end{array}$ & 1,124 & 1,124 & 1,124 \\
\hline $\begin{array}{l}\text { R-squar } \\
\text { ed }\end{array}$ & 0.135 & 0.300 & 0.135 \\
\hline
\end{tabular}

t-statistics in parentheses

$* * * \mathrm{p}<0.01, * * \mathrm{p}<0.05, * \mathrm{p}<0.1$

\subsection{Robustness test}

In order to ensure the effectiveness of the empirical results, this paper tests the robustness of the empirical results. In this paper, we choose the method of replacing 
the explanatory variables, replace the logarithm of government subsidies with the intensity of government subsidies, repeat the above regression analysis steps, and the results are roughly the same as the above.

\section{Conclusion and suggestion}

This paper selects the relevant data of 501 listed energy companies from 2015 to 2019 to study the relationship between government subsidies, R\&D investment and enterprise growth. Through the above regression analysis, we draw the following conclusions: first, government subsidies and energy source enterprise performance is significantly positive correlation. The greater the government subsidies to enterprises, the more conducive to the growth and development of enterprises. Second, there is a significant positive correlation between government subsidies and R\&D investment of resource-based enterprises. After enterprises get government subsidies, the amount of R\&D investment will increase. Thirdly, R\&D investment has a significant partial mediating effect between government subsidies and enterprise growth. Government subsidies can not only directly affect the growth of enterprises, but also affect the growth of energy enterprises through R\&D investment.

Based on the above conclusions, this paper puts forward the following suggestions to the government and enterprises: at present, the energy industry is paying more and more attention to the R\&D of science and technology, and increasing R\&D investment every year. However, compared with similar enterprises in developed countries, there is still a gap in the overall level of R\&D investment of energy enterprises in China. It is far from enough to increase investment in science and technology only by the efforts of enterprises themselves. According to the research results, government subsidies can significantly promote the R\&D investment and enterprise growth of energy enterprises. Therefore, the government should fully realize the importance of technological innovation, encourage the development of China's energy industry from resource driven to innovation driven, and help enterprises develop healthily and stably. The government not only provides support for enterprises in terms of funds, but also continuously optimizes the supporting policies for enterprises, which can be continuously optimized from the aspects of Taxation, law, personnel training, etc. Government departments should help enterprises optimize the external environment, so that the energy industry can actively promote R \& D, achieve more and better innovative results, and build core competitiveness. In addition, the government should improve the business environment, optimize financing methods and provide good financing channels for the energy industry.

If enterprises want to give full play to the positive role of government subsidies, they must improve the utilization efficiency of government support through a series of means. First of all, enterprises should enhance the enthusiasm for technology research and development, improve the enterprise technology research and development system and the corresponding system construction, and provide a solid institutional guarantee for research and development. After obtaining government subsidies, enterprises should timely disclose the details of the use of subsidies, make use of the power of government and social supervision to reasonably allocate subsidy resources, and improve the efficiency of the use of subsidies. And enterprises should improve internal management and improve operational efficiency to provide a good internal environment for technological innovation and $\mathrm{R} \& \mathrm{D}$.

\section{Acknowledgments}

Funding Resources: Liaoning social science planning fund"Study on precise matching of business environment index evaluation and optimization measures in Liaoning pilot Free Trade Zone"(L19DJY002)

\section{References}

1. Zhang shuanxing, Fang Xiaojun, Li Jing. Research on the impact of $R \& D$ investment on growth of GEM listed companies: Based on the moderating effect of equity structure [J]. Research on science and technology management, 2017, 37 (8): 143-149

2. Xu Fang, Cheng Kequn, Tan Qinghua. Government subsidy, R\&D investment and enterprise growth [J]. JOURNAL OF SHENYANG UNIVERSITY (SOCIAL SCIENCE EDITION), 2020,22 (05): 590-595

3. Wei Zhihua, Wu Yuhui, Zeng Aimin. Rent seeking, financial subsidies and corporate growth: Empirical Evidence from energy concept listed companies [J]. Economic management, 2015,37 (01): 1-11

4. Li Chuanxian, Liu Xiaoyu. Research on the relationship between government subsidies and the growth of private enterprises $[\mathrm{J}]$. Friends of accounting, 2016 (10): 94-97

5. CERQUA A, PELLEGRINI G. Do subsidies to privatecapital boost firms' growth? A multiple regression discon-tinuity design approach $[\mathrm{J}]$. Journal of Public Economics,2014,109:114-126

6. Kong Dongmin, Li Tianshang. Does government subsidy improve corporate performance and social responsibility? [J]. Securities market guide, 2014(7): 26-31

7. Zhang Shuanglan, sun Hui. R\&D investment, government subsidies and internationalization performance: Based on the empirical evidence of "going global" manufacturing enterprises [J]. Research on science and technology management, 2019,39(14): 137-145

8. Zhu Pingfang, $\mathrm{Xu}$ Weimin. The impact of government's science and technology incentive policy on R\&D input and patent output of large and medium-sized industrial enterprises: An Empirical Study of Shanghai [J]. Economic research, 2003 (06): 
$45-53+94$

9. Luan Fugui, Ma Qinqin. Government subsidies, R\&D investment and zombie enterprise performance [J]. Finance and accounting bulletin, 2019 (15): 91-94

10. Zhu Zhihong, Gao Jie, Xu Ping, Xue Dawei. The impact of corporate governance on the financial competitiveness of Energy listed companies from the perspective of life cycle $[\mathrm{J}]$. Business accounting, 2019 (03): 9-14

11. Su Yi, Lin Yunong. Research on the impact of government subsidies on R\&D investment of new energy enterprises [J]. Scientific management research, 2021,39 (01): 102-110 